\title{
LEGAL EDUCATION IN THE RECRUITMENT MARKETPLACE: DECADES OF CHANGE
}

\author{
ABBIE WILLARD THORNER*
}

The legal marketplace has undergone tremendous changes over the past three decades. Expansion of initial employment opportunities, competition among employers to hire top candidates, and decreasing likelihood of long-term affiliation between a new lawyer and his or her first employer affect not only the recruitment process, but legal education itself. This essay will first trace developments in legal recruitment from the 1960's to the present, then attempt to predict how legal recruitment will contimue to develop and affect legal education as a whole.

\section{The Past Thirty Years of Law Placement: An Overview}

Once upon a tine, law schools were in the business of educating and training new lawyers. Period. Before the early 1960's, few law schools devoted significant attention to precise admission criteria. At the other end of the legal education process, few schools devoted much attention to job placement. ${ }^{1}$ A natural self-selection seemed to take place: students gravitated to appropriate schools, and after performing adequately (or better) for three years, they joined law firms with which they would then spend the rest of their lives. The job search, if it was conceptualized formally at all, was viewed with the saine seriousness of purpose and sense of permanence traditionally associated with entering a marriage. Professional positions were indeed marriages of sorts for lawyers in this era. Lifelong commitment, maturing from associate to partner, and unceasing loyalty to the firm characterized most of these "til-death-didthem-part" alliances.

By the late 1960's, the Vietnam War had contributed a new incentive to consider professional school, and law became a very popular field as both a means and an end in a socially active time. The supply of new lawyers seemed to be increasing faster than the demand, though general School.

* Assistant Dean, Career Planning and Placement Center, Georgetown University Law

1. For a brief discussion of the history of law school placement programs, sce Feerick, JobPlacement Services Needed in Law Schools, Nat'l L.J., Dec. 31, 1984, at 24, col. 3. Harvard Law School established one of the nation's first formalized placement offices after World War II. Id. By the early 1970's, there were about 25 formal placement programs. Id. By 1984, every accredited law school in the United States had a placement service. Id. at col. 4. 
economic health led to a steady pattern of growth in the number of available positions. Because of the increasing supply of graduates, law schools and employers alike looked to more specific criteria in their admission and hiring policies. For the first time, there could be no assumption that an association between a new lawyer and a firm would be permanent. Partnership tracks, especially in larger firms, became inore selective as the supply of new talent nourished the entry-level positions but promised to gorge the more senior-level positions. Not every marriage between lawyer and firm lasted. Some senior associates, confronted with less than even chances for partnership, moved to more promising employment settings.

The late 1970's found law schools and all legal employers enjoying an einbarrassment of riclies. Applications to law schools peaked and ever-increasing numbers of new lawyers approached what had become a well-organized, highly structured job market, witl, in many geographic locations, ever-escalating hiring criteria and grade standards for job offers. The law school's reputation, admission requirements, faculty visibility, and educational program strength became factors in an increasingly competitive marketplace that narrowed its focus to each apphicant's admission credentials and actual law sclool grades or class standing. The quality of a candidate was measured by both the individual candidate's academic performance and the perceived rank of that candidate's law school. Having met increasingly stringent qualitative criteria, the newly hired lawyer then embarked on an early career that was not always to result in a lifelong association with an employer. The law of supply and demand and other econoumc forces affecting the legal profession rapidly dimimished the odds that the marriage would last and lead to partnership in a firm, general counsel status in a corporation, or senior attorney status in a public interest group.

The professional school and private sector growth rate of the 1970's produced an even larger legal profession in the 1980's. Despite the burgeoning number of new lawyers entering the profession, ${ }^{2}$ the supply of lawyers apparently has not outstripped the deinand. ${ }^{3}$ Today, large law firns with more than 200 attorneys are common, and the "mega-firm"

2. As of 1983 , there were approximately 650,000 lawyers in the United States. See NATronal association for law Placement, Inc., Class of 1983 Employment Report and Salary SURVEY 3 (1985) [hereinafter 1983 EMPLOYMENT REPORT]. At that time, there were nuore than 40,000 new bar adnissions each year, and the annual net growth in the profession approached 25,000 .

3. A review of National Association for Law Placement Employment surveys for the years 1973 to 1983 reveals that the percentage of new lawyers obtaining employment within nine nonths of law school graduation has renained relatively stable-in the $90 \%$ range-over that ten-year period. Data for 1984, 1985, and 1986 will be available in Spring 1987. 
with more than 400 attorneys in various offices throughout the country is no longer an oddity. Many private firms are growing at unprecedented rates; large firms and mega-firms project growth rates approaching or even exceeding twenty-five percent by the end of this decade. Such sheer volume has had dramatic effects on the marketplace. Adaptations in that marketplace are apparent in several trends. These trends include a search for new logic to guide hiring and retention, an increase im emphasis on recruitment, an expansion in the scope of recruitment practices, and recent proliferation of employment categories for lawyers. Each of these trends merits examination.

\section{A. Search for a New Logic to Guide Hiring and Retention.}

Private firms have traditionally structured their growth on a pyramid structure. In the mid-twentieth century, the profitability of most law firms was based on a leverage system in which associates formed the base of the pyramid, with ever-decreasing numbers of lawyers remaining in the firm as the pyramid rose to the pinnacle, the most semior partners. This pyramid model of law firms never existed in its purest form, even among the large firms in which it originated. But medium and smaller firms that recognized its economic promise adopted its general pattern in modified form. Firms calculated numbers and formulas that attempted to capture the proportions necessary for the health of this pyramid economy. Roughly three to four times the number of anticipated future partners had to be hired at the associate level. The ratio of associates to partners had to be 1:1, 2:1, or 3:1, depending on the size and type of practice. Under a typical formula, associates were expected to bill three times their annual salary, with one-third of that amount to be used for the associate's salary, one-third to be used for firm overhead (space, rent, equipment, furnishings, supplies, and support services), and one-third to be divided annually or biannually by the partnership. The numbers and proportions varied considerably, depending on the firm's location, size, and style of management. Many firms operated on the assumption inlierent in the pyramid model, without recognizing or analyzing any basis im theory.

The pyramid, for its own structural soundness, lad three prerequisites: (1) an appropriate number of attorneys entering the structure; (2) an appropriate percentage of those attorneys leaving the structure at appropriate intervals, preferably by voluntary attrition; and (3) continuous organizational growth.

In the 1950's through the 1970's, legal education was feeding attorneys in growing numbers into the mainstream of the profession. With as many as $60 \%$ of the 40,000 new lawyers entering private practice each 
year, ${ }^{4}$ the potential number of new associates more than exceeded the pyramid's demand. Anticipating continued growth, many firms then hired froin this large talent pool what, in retrospect, were too many inexperienced lawyers. Thus the first requirement for a structurally sound pyramid was undercut.

The second requirement, that these attorneys leave the firms in numbers consistent with firm growth, was similarly thwarted by changing economic forces. As overhiring led to decreased percentages of new partners or to the need for layoffs in some firms, increased inobility within the profession led to undesirably high levels of attrition im other firms. Small, medium, and large firms alike seemed to be faced with feast or famine and the growing awareness that the traditional pattern of progression up or out of the pyramid no longer produced the appropriate nuinbers of attorneys at each level.

The third requirement, that the growth of the organization continue into perpetuity, became an unrealized pipedream for many firms. In order to remain profitable while absorbing increasing numbers of partners, firms had to brimg increasing numbers of associates into the base. All these personnel increases heightened the need for increasing numbers of clients, client matters, and fees. The spiral could not and did not continue indefinitely. The economic downturn of the late 1970's brought with it more cost-conscious clients ready to limit legal fees, more corporations pulling legal matters in-house for cost and quahity control, and fewer small businesses and private citizens willing or able to pay for professional legal services. The entire framework of the pyramid came into question. The leveraged system of private firm profitability and the very organizational principle of many firms no longer seemed to serve the private bar well.

"Business," "competition," and "productivity" found a place alongside "partnership," "collegiahty," and "permanence" in the traditional jargon of the profession. The difference between the new vocabulary and the more traditional constructs is not merely one of semantics, but of emphasis. The focus among private practitioners has, of necessity, moved to a more business-oriented search for an economic structure that will bring new or continued econoinic health to private practice.

4. See, e.g., L. Vogt, From Law School to Career: Where Do Graduates Go and WHAT DO THEY DO? 23-24 (1986) (62\% of graduates of seven northeastern law schools surveyed had first job after law school graduation in private practice). 


\section{B. Increased Emphasis on Recruitment.}

With a questioning of the old system has come an increased assertion of competitiveness. Eniployers of all sizes and types vie for the best and brightest in the second-and third-year classes of law schools across the nation. No longer is on-campus law school recruiting the doinam solely of the large firm or government agency. Within the last decade, medium and smaller firms, public interest organizations, corporations, and businesses have arranged interview dates nine to twelve months in advance of law students' eniployment availability. More and inore einployers are requesting interviews with or direct contact froin students at law schools of all sizes, geographic locations, and reputations.5 The recruitment process is no longer an intrusion into the academic calendar to be borne solely by a few select law schools. ${ }^{6}$

As more and more einployers compete for law students and new lawyers, an eniphasis on convincing or enticing interested applicants to join the organization has replaced selection through evaluation of paper credentials as the primary focus of the interview process.

A concern is spreading im both the academic community and the employment sector that declining apphications to law scliool ${ }^{7}$ may ultimately result in a "less qualified" employment pool. If the best and the brightest are not applying to law schools, and if law schools are lowering their own admission requirements in order to fill class seats, ${ }^{8}$ then objective measures such as class standing or grade-point average, traditionally viewed as indicators of quality, becoine only relative ineasures. In the face of the increased competition for new lawyers, many employers have

5. Although the increase in recruitment activity would seem to promise more opportunities for more students at more schools, such an assumption is far too rational for the current market. More employers have entered this fray, but regardless of the employer's size, type, or place within the hierarchy of desirable career options, most of them attempt, at least initially, to compete for a finite percentage of students at a limited number of schools. So far, increased recruitment has not resulted in broad distribution of career options and job offers.

6. Professor Roger Cramton, former President of the Association of American Law Schools, has described the disruption that results from on-campus interviewing:

Law placement as a whole is now an engine totally out of anyone's control, a market response to the cumulative actions of thousands of legal employers and job candidates, with law schools as the intermediaries and the education program as the victim.

Cramton, President's Message on Improving Student Placement, AALS NEwsL., Sept. 1985, at 2.

7. The number of applicants to ABA-approved law schools decreased by $12 \%$ from 1982 to 1984. Vernon \& Zimmer, The Demand for Legal Education: 1984 and the Future, 35 J. LEGAL EDUC. 261, 261 (1985). During the same period, first-year enrollment declined by only $3 \%$. Id.

8. Vernon and Zimmer analyzed the LSAT scores and undergraduate grade point averages of applicants to ABA-approved law schools from 1980-81 to 1983-84 and concluded that the collective academic credentials of students who entered law school in 1984 were not as good as those of students who entered in 1982. Id. at 263-66. If this trend continues, Vernon and Zimmer predict a decline in the quality of law school graduates unless law schools impose strict quality standards and dismiss unqualified students before graduation. Id. at 266. 
moved to broader-based hiring criteria. The lack of reliance on objective criteria, coupled with the need to seek out top-caliber candidates, has led employers to become much more activist in their recruitment activities. Employers are seeking alternative ways of reaching applicants. The more creative participants in this escalating competition for new lawyers have developed extensive marketing strategies for producing the desired yield of talent from a given school. New strategies include firm-sponsored social functions, mail campaigns to individual students or student groups, and increased employer visibility in the educational and service functions of the school. Employer atteinpts to become better known in the law school community have indirectly benefited alumni and development office functions, adjunct faculty rosters, and placement office programs on career alternatives.

\section{Expansion of Recruitment Practices.}

In a more direct attempt to attract students, the legal profession has entered the world of inarketing. Firms and organizations who would not consider an aggressive marketing approach to client development have turned considerable energy to inarketing their image to potential new recruits. Detailed firm resumes, glossy four-color brochures, and professionally produced videotapes have been added to the stock of employer information found in most placement office resource centers. Recent salary wars provide an even more striking example of the legal profession's true entry into the world of competitive hiring. ${ }^{9}$ When large New York firms initiated the escalation with a salary jump to the mid- $\$ 60,000$ range $^{10}$ and provided up to $\$ 20,000$ incentives for judicial clerkship experience, ${ }^{11}$ their counterparts in other metropolitan areas followed suit. Government and public interest organizations will surely feel the shock waves of these dramatic increases. And the ripples will inove througl the ranks of the profession as well. A federal judge with extensive experience may see law clerks leave after a two-year judicial clerkship for jobs paying as much as or more than the judge earns. The emphasis on and expansion in recruitment practices have created a grossly disproportionate level of compensation for the value of the experience and service pro-

9. As early as 1968 , the legal profession attracted media attention when starting salaries at some Wall Street firms increased in one year from $\$ 9500$ to $\$ 15,000$. See Zion, New Lawyers to Find Salary Market Bullish, N.Y. Times, Feb. 15, 1968, at 45, col. 5. The jump signaled the beginning of the salary spiral that has continued. See Metaxas \& Rosen, "Salary Wars" Still the Talk of New York, Nat'1 L.J., March 9, 1987, at 1, col. 3 (discussing rumor that salaries at major New York law firms may rise to $\$ 80,000$ in fall 1987).

10. See Hengstler, If I Can Make It There.... A.B.A. J., Aug. 1986, at 28; Lewin, At Cravath, $\$ 65,000$ to Start, N.Y. Times, Apr. 18, 1986, at Dl, col. 3.

11. See Hengstler, supra note 10 , at 28 . 
vided by the lawyer at the entry level. The pressures of that disproportion will continue to be felt throughout the profession.

As competition via salaries has increased, so too has the creative approach to recruitment practices. This creativity is most obvious at the law schools that have benefited from the willingness of a growing number of employers to consider the relevance of a widening range of hiring criteria. Law firms, government agencies, and public interest groups alike are moving toward a corporate model of personnel selection. The traditional concern with law school grades and class standing is still important, but a more thorough review of other credentials usually accompanies it now.

Recruitment cost control has led some mediun and large firm employers to hire "third-party interviewers," private consultants who are professionals experienced in selection techniques. Although this approach to law school interviews is a relatively recent phenomenon, its initial results seem promising for employers, schools, and students. This particular development will further increase the business-oriented approach of recruitment practices because it will increase the einphasis on personnel selection techniques as practiced by experienced personnel specialists. Most schools will benefit fron exposure to the broader base of einployers represented by these consultants, and the students who interview with these professional interviewers will find the interchange to be more structured, objective, and job-related than interviews conducted by attorneys with hittle or no formal training in selection techniques.

Beyond the cost-control forces that drive many einployers to expand their recruitment practices, nrarket forces also broaden the accepted means of acquiring new attorneys. The increased mobility of lawyers has led to the development of a new service industry, the legal search firm. ${ }^{12}$ Patterned after executive search organizations, legal search firms are in the business of brokering professional talent. Search firms can help employers locate talent inaccessible through the traditional channels of law school recruiting, advertising, word of mouth, and unsolicited resumes. ${ }^{13}$ Legal search consultants encourage, contribute to, and profit by the escalating movement within the profession. Although most legal search firms do not serve applicants during or immediately following law school, their emphasis on lawyers with up to

12. The importance of legal search firms has increased dramatically in recent years. The number of search firms serving the New York metropolitan area has grown from 20 to 50 in the past 10 years, and search fees have increased four times as much as attorney salaries. See Strudler \& Thieberger, How to Hire, Retain Lateral Associates, Nat'l L.J., June 30, 1986, at 16, col. 1.

13. See Kanarek, Choosing and Using a Legal Search Firm, Nat'l L.J., Sept. 29, 1986, at 14, col. 1. 
seven years of experience ${ }^{14}$ has created a much more active market for relatively new lawyers.

By fueling the activity of the market, the legal search consultant has had a dramatic impact on the role and function of law school placement offices. These offices can no longer be content with providing services to their enrolled students, but must now expand their programs to include services for alumni who are in increasing numbers reentering the job market several times within the ten years after they leave law school. The demand for such expanded services in tuition-funded offices has created a crisis of resources. Law schools and their placement offices are now expected to provide alumni with lifelong career services in the form of job opportunity notices, counseling, resume preparation, and job negotiation strategies. If professional mobility continues to increase and law firms continue to grow at projected rates, the magnitude of issues surrounding law school alumni placement services will only continue to grow.

\section{Proliferation of Employment Categories for Lawyers.}

Throughout the legal profession, new personnel categories for lawyers are proliferating. Private firms have begun to act less and less like partnerships and more and more like employers. The progression from associate to partner or junior attorney to senior counsel is no longer a certain or in some cases even probable path. Terms such as "permanent associate," "senior lawyer," and "staff attorney" have become familiar as labels for the lawyer in private practice who is a paid employee of the firm rather than an owner or profit sharer in a partnership. ${ }^{15}$ Similarly, "of counsel" arrangements, in the past reserved for senior attorney consultants or those approaching or at retirement status, are now defined by varying loose arrangements between firms and attorneys who as "of counsel" really function as private contractors. Even traditional partnerships are no longer simply partnerships; they may be bifurcated to include individuals with equity and nonequity status or structured to include inultiple role distinctions on a hierarchical ladder of compensa-

14. A partner in a New York-based legal search firm has described the ideal candidate for placement by such a firm as

a fairly junior associate at a large to medium-sized law firm with excellent academic credentials, who is looking for a position practicing law in his or her current field of expertise with a law firm or-in some instances-a financial institution or corporation.

Id. Based on these criteria, at least $95 \%$ of all lawyers will have difficulty finding a legal search firm interested in working with them. Id. at cols. 1-2.

15. See, e.g., Lewin, Law Firms Add Second Tier, N.Y. Times, Mar. 1, 1987, at 29, col. 3. 


\section{tion and management. ${ }^{16}$}

This proliferation of employment categories is already having a profound effect on the attitude of individual lawyers. As the legal profession evolves from an elite group to a cluster of employment categories, it inspires less collegiality and loyalty because increasing numbers of its meinbers are employees rather: than partner-participants in its predominant structure, the private firm.

\section{LAW Placement In the 1980's AND Beyond}

Future developments in the legal job market will probably continue to reflect the broader-based, more business-oriented approach to hiring evident in recent years. The slieer number of attorneys ${ }^{17}$ has had a significant effect on the gross national product. In 1982, the nation's more than 115,000 law offices liad receipts of thirty-four billion dollars. ${ }^{18}$ In contrast, the nation's 95,000 law offices surveyed in 1977 accounted for only twelve billion dollars of the gross national product. ${ }^{19}$ This pattern of growth shows no sign of abating.

\section{A. Change and Constancy.}

During the 1970's, massive changes occurred in the composition of the legal profession. Increasing numbers of woinen and minorities were admitted to and graduated from law schools. As the National Association for Law Placement reported,

[b]y 1980, the number of women attorneys had grown to $44,185 \ldots$ [an increase of $350 \%$ since 1970: By 1983, $12 \%$ of all attorneys were women, and almost $36 \%$ of all graduates of the class of 1983 were women. Minorities were $8.3 \%$ of the 1983 graduating class. They are a statistically small part of the licensed lawyers in this country, since only around $6 \%(37,925$ of 650,000$)$ are minorities. Despite increases in women and ininorities, the profession remains overwhelmingly white and male.20

In addition, because of the influx of the "babyboom" generation into the economy in general, and into the legal profession in particular, the profession's median age dropped from forty-five or forty-six in 1970 to forty

16. For a brief description of several firms' experiences with tiered partnership structures, limited-term contracts for attorneys, and other modifications of the traditional pyramid structure, see Marcotte, Contract Associates, A.B.A. J., Feb. 1987, at 24.

17. In 1983, there was one lawyer for every 363 Americans. See supra note 2.

18. 1983 EMPLOYMENT REPORT, supra note 2 , at 3.

19. Id. at 115 .

20. Id. at 2. Enrollment figures at ABA-approved law schools show continuing increases in the percentages of women and minority law school students. Forty percent of the students enrolled in J.D. programs in 1985 were women, and $10.4 \%$ were minority students. See Silas, End of an Era, A.B.A. J., June 1986, at 17. 
in $1980 .{ }^{21}$

Showing no signs of variation during this period, however, are some patterns in einployment trends. Although the numbers of law school graduates accepting employment in government and public interest organizations declined, the percentage of graduates entering private practice remained relatively constant. ${ }^{22}$ Unfortunately, opportumities in the public interest and public service sector slow no signs of increasing im the near future, so the trend toward minimal government and serviceoriented employinent will probably contmue, fueled by the widening gap between public and private entry-level salaries.

The general demographics of American society also reveal a decline of particular interest in law school. Projections indicate that the number of twenty-two-year-olds in the United States population will fall from a high of 4.5 nillion in 1983 to approximately 3.8 million by $1993 .{ }^{23}$ Although law school admissions and the resulting talent pool for the profession have declined in varying degrees across the country, the full effect of the demographic decline has not yet hit the professional scliools that feed the inarket. As the cost of a legal education increases, the admissions pool narrows, einployers' coinpetition for applicants intensifies, and the costs of hiring and retention escalate, the financial balance of the law firm recruitment market will be tenuous at best. Law school admissions and placement offices will be asked even inore difficult and probing questions about the nuarketability of a law degree froin their institution.

\section{B. Roles and Trends.}

The roles played by individuals in the legal profession during the coming decade will probably differ radically from those previously expected of most lawyers. A recent study analyzing the mobility and career patterns of law school graduates reveals trends that will affect the entire future of the profession. This study, ${ }^{24}$ conducted by the Harvard

21. See Silas, supra note 20 , at 17 .

22. For more specific regional and job category data, see the annual National Association FOR LAW Placement Employment and SAlARY SuRvey published by NALP, Washington, D.C.

23. See Vernon \& Zimmer, supra note 7, at 272. But note that the law school applicant pool is by no means composed exclusively of 22-year-olds. In fact, the median age of applicants remained relatively constant at about 25 from 1981 to 1984 . Id. at 272-73.

24. The Harvard Law School Program on the Legal Profession with support from the Law School Admission Council/Law School Admission Services and the Alfred P. Sloan Foundation conducted the study by mailing a survey to approximately 6800 law school graduates from seven northeastern law schools. Of these, more than 3400 (approximately 50\%) returned their questionnaires which were then analyzed using a variety of dimensions. The schools participating-Boston College, Boston University, Columbia University, University of Connecticut, Harvard University, Northeastern University, and Suffolk University-though clustered geographically, were diverse in 
Law School Program on the Legal Profession, tracked the members of the classes of 1959, 1969,1974, and 1981 in an attempt to determine their mobility, the flexibility of their law degree, their job changes, salary patterns, and other career-related characteristics. Six of the study's inany findings are important for considering future trends in the profession:

(1) Although most respondents were employed in traditional law practice positions ( $79 \%$ ), more than $20 \%$ had moved from law to "lawrelated" or totally "non-law-related" jobs; 25

(2) The longer a class had been out of law school, the greater was the proportion of that class in "law-related" or "non-law-related" positions; 26

(3) Less than one-fourth of the classes of 1959, 1969, and 1974 were still employed by their first employer, and approximately one-half of the class of 1981 had already changed jobs; 27

(4) Large incoine gaps between large-firm practitioners and smallfirm practitioners widened considerably the longer the group had been out of law school;28

(5) The great majority $(70 \%)$ of respondents resided in the same inetropolitan area where they had taken their first job after law school;29

(6) The importance of "outstanding school record" as a criterion for employment captured only $5 \%$ of the responses to a question asking what characteristics the respondent would seek in a candidate to fill his or her own position. ${ }^{30}$

The first of these findings, the movement of lawyers away from traditional law practice, is not surprising to individuals in law school placement offices. Front-line counselors have reported for a number of years that new graduates in increasing numbers were considering nontraditional alternatives to practice. The extent to which the movement away from law has occurred after the initial post-law school job, however, is enlightening. These more experienced attorneys are individuals who found jobs in traditional fields, tried their hands at the skills of the profession, and then chose not to continue in traditional lawyering. This finding undercuts a basic assumption within sonte law schools that only

terms of size, private and public funding, national and regional applicant pools, and availability of day and evening educational programs. I. VoGr, supra note 4. A full report of this study is available from the Harvard Law School Program on the Legal Profession.

25. L. VoGT, supra note 4, at 9-10.

26. Id. at 10 .

27. Id. at 28-30.

28. Id. at 61-62.

29. Id. at 7.

30. Id. at $71-73,79$. 
those who cannot obtain jobs in private practice choose other alternatives.

Surprising also are the statistics that indicate that people becoine inore likely to move away from the legal profession the longer they are out of law school. This finding imphes that the exodus from traditional practice is not limited to entry-level career crisis situations, but is an important demographic fact for all law school alumm and development offices that work with lawyers later in their careers. Similarly, the fact that fewer than one-fourth of the respondents ten or inore years out are with their initial employer should provide law schools and their placement offices a further indication of the need for lifelong career counseling services. A placement office tliat has helped a student obtain a job has only served to launch a career that, if the study is reflective of the profession as a whole, ${ }^{31}$ will take inany turns and changes.

The mcoine gaps noted in the study are consistent with the disparity in entry-level salaries at firms of various sizes. But because this gap, like the one between private and public sector, seems to widen the longer the group lias been practicing, the numbers and types of individuals who will apply to law school in the future inay be even more affected by the career options and earning potential they project for themselves. The salary structure within the profession at present is moving toward a two-tier high or low option rather than the continuum of opportumities, most of which potentially led to a relatively affluent lifestyle, that lawyers could anticipate in the past. If this trend contmues and law schools themselves become associated with either one or the other of the two tiers, the effect on the applicant pool of those schools could be dramatic. ${ }^{32}$

In contrast to the inobility and change reported in the Career Path study, the geography of the first career choice seemed to provide soine constancy. This geographic stability has imphications for law school alumni networks and for admissions office development of alternative applicant pools. Although the geograplic consistency is understandable, given the difficulties of long distance job scarches, its effect on the

31. Although the seven northeastem schools that participated in the study are geographically limited and therefore not a microcosm of the American law school universe, their diversity in size and characteristics contributes to the generality of the study results. Still, one must be careful not to draw too many national conclusions based on a regional sample. Even if the participant schools may be judged as representative, the northeastern job market available to their graduates is not typical of job markets in other regions of the country. The predominance of large firm practice in much of this region precludes broad generalizations that apply to other more diverse regions.

32. Vemon and Zimmer recognize that the perceived hierarchy of law schools has a strong influence on job placement of graduates and emphasize that, particularly in view of the declining applicant pool, "honesty and reasonable 'consumer protection' demand that the placement potential of the individual school be disclosed in full prior to enrollment." Vernon \& Zimmer, supra note 7, at 280. 
demographics of a law school's sphere of influence transcends mere individual einployment concerns. Law schools interested in affecting the geographic distribution of their influence may do well to devote resources to nourishing their established geographic strongholds or to cultivating targeted new ones.

Finally, a finding of significant importance to the academic community is the apparent decrease in emphasis on academic performance as a criterion for lateral employinent. If the respondents' ranking of "outstanding school record" reflects a general assumption within the inarketplace, then grades and class standing will soon begin to disappear from interview questions and evaluation forms. Althougl many law schools have labored for years to convince einployers of the merits-beyond academic performance-of all their students, a wholesale acceptance by employers of this argument could have far-reaching effects. In the absence of seemingly objective standards such as the numbers associated with acadernic performance, employers will contimue to search for alternative ways to distinguish applicant quality. ${ }^{33}$ An examination of who is qualified and by what standards those qualifications are measured may force the acadenic community as well as the private sector to review their long-held standards of evaluation.

\section{IMPLICATIONS FOR LEGAL EDUCATION}

Employers in the legal profession have, of necessity, begun to adapt to the career movernent and forces of the marketplace. If legal education is to thrive, its responsiveness to these trends is similarly critical. Traditionally, with feet im both worlds, one in the bar, the other in the halls of scholarly research and discourse, law schools have adapted to the requireinents of both with varying degrees of success. The pressures associated with declining admission applications combined with the forces at the other end of the academic process, those resulting from employment trends, are creating an environment that necessitates such adaptation. Just as law firms and other types of employers have found that the responsibilities of hiring do not end when the associate begins work, law schools are finding that their responsibilities to the careers of their new alumni do not end with the first "permanent" position. Law school

33. Although there does exist information indicating which qualities the survey respondents considered valuable, see supra note 24 , that information is of limited utility unless employers can and will devise ways to assess whether job applicants possess those qualities. Respondents placed the highest value on good judgment, common sense, creative problem solving, and the ability to work well under pressure. L. VoGT, supra note 4, at $72-73$. The difficulty of measuring these qualities probably deters employers from using them for evaluation purposes. Some proponents of using academic credentials as a primary criterion might argue that academic performance correlates with these factors to some extent. 
placement offices are now providing more than mere job notices and accoinpanying career counseling for their alumni. Many are being called on by individual alumni to function as "outplacement" consultants, a service provided to ease, through counseling and the availability of job search resources, the transition fron 1 one job to another. Others are experiencing pressure from employers to provide them witl more information on the availability and credentials of alumni in searcli of lateral job changes. Both alumni and employers alike form a new constituency for placement offices established and funded for the sole purpose of student service.

The impact of the trends in the marketplace most certainly will not be confined to the placement office. As critical as that department is to student and employer perceptions of the scliool, the placement office will also be required to function as a conduit for clianneling information on market forces to other law school departments. Many departınents will feel the effects.

The most direct impact will be on alumni services and development offices. The increased mobility of lawyers in general has inspired alumm from a variety of law scliools to return to their schools, not just for placement assistance but also for a variety of auxiliary services. As law schools have sought to shed their tuition dependence, they have sought out their experienced graduates for financial support; these graduates, in turn, have called on the law schools for more resource services. The response to these requests has taken a variety of forms, ranging from extensive library privileges to school-sponsored local programs and schoolinitiated regional networks. The message from experienced alumni to the law school is clear: the need for lifelong, school-sponsored ties is increasing.

Traditionally, law schools have attempted to meet a simpler form of this growing need by offering Contmuing Legal Education programs. More and more law school administrative offices are hearing the call, not just to support the academic function in the legal education process, but to respond to inquiries and requests by and for alumni long after the law degree has been conferred. Unfortunately, these requests are not always positive. Registrars throughout the legal education community receive credential verification calls long after the first post-law school job has ended. ${ }^{34}$

Admission offices will also sense the heightened emphasis on recruitment. Potential law school applicants may "interview" their interview-

34. These requests do not always lead to happy resolutions of troubling employment issues. See Middleton, Lawyer Disbarred; Lied to Employers, Nat'l L.J., Oct. 27, 1986, at 3, col. 1. 
ers in search of information about employment and salary data at a given school. Committees on curriculum development and academic standards are under pressure, too, as recruitment needs pressure them to provide course offerings and refine performance standards in ways that make these offerings and standards more directly related to hiring and retention in the employment sector.

Although much of this increased pressure on law schools and their service offices is a direct result of attoruey mobility, ${ }^{35}$ it is also a function of the changing role of law school administration. For a variety of reasons already discussed, law schools have become more consumer oriented. As potential applicants increase their scrutiny of the alternatives available after the investment in a legal education, law schools are turning their attention to the processes, such as admissions, public relations, and placement, that provide transition into and out of the educational environment. The entire system of processes associated with legal education will have to become even more accountable to the consumers who use it as a ineans to an end, a professional career.

If the role of law school administration is changing, so too is the profession it trains. No longer is the function of the practicing lawyer confined to providing legal services; instead, it has expanded to include the selling of those services. That "sale" does not just occur between the attorney and the client, but may also include the relationship of attorney to employer. Once again, mobility in the marketplace has affected the definition of roles and has broadened the parameters of the skills a lawyer may sell to an employer. The implications of this new attorney role are profound in their effect on law schools. The numbers, characteristics, and attitudes of prospective new lawyers will be affected dramatically by the changing role of practicing attorneys in society.

As growing numbers of lawyers move from one employment option to another, as private firms grow in size and become more complex business entities, and as economic forces continue to drive the profession to a more differentiated hierarclical structure, employer recruilment will move even closer to a competitive corporate model. Career planning and placement offices in particular will experience increased pressure. This pressure will take the form of more requests for information by the external world of employers and requests that more resources be made available to placement office constituents, the students and alumni served by the law school. The challenge to legal education, however, transcends these service offices to encompass the role of the institution itself. Legal

35. For a discussion of the possibility that such mobility may not continue, see Strudler \& Thieberger, supra note 12 . 
education is now itself a part of the multimillion-dollar market that buys, sells, and markets lawyer skills. The role it will play in the development and dehivery of those skills will imspire the change and provide the challenge ahead. 